\title{
PENERAPAN SISTEM REKRUTMEN PESERTA DIDIK DALAM MENINGKATKAN MUTU LEMBAGA PENDIDIKAN DI SMPIT AL FITYAN SCHOOL GOWA
}

\author{
SARTIKA', MISYKAT MALIK IBRAHIM ${ }^{2}$, BAHARUDDIN ${ }^{3}$ \\ ${ }^{1}$ Institut Parahikma Indonesia, 2,3Universitas Islam Negeri Alauddin Makassar, \\ Indonesia \\ Email:1 1tika10azura@gmail.com, ${ }^{2}$ misykat.mmi@gmail.com, 3baharuddinjepot@gmail.com
}

\begin{abstract}
Implementation of the Student Recruitment System in Improving the Quality of Educational Institutions at SMPIT Al Fityan School Gowa

This study aims to: 1) describe the input of student recruitment at SMPIT Al Fityan School Gowa; 2) describe the process of student recruitment at SMPIT Al Fityan School Gowa; 3) describe the output of student recruitment at SMPIT Al Fityan School Gowa. This research uses descriptive qualitative research method. The sources of research data are the secretary of the foundation, the headmaster, vice principal of student affairs, vice principal of curriculum affairs, administration, chairman of the PPDB committee, secretary of PPDB, and parents of students. The data collection method used is the interview, observation and documentation method, with data processing and analysis techniques carried out through three stages, namely data reduction (data reduction), data presentation (data presentation) and Conclusion Drawing or Verification (drawing conclusions or levers). The results of this study indicate that: 1) the student recruitment input at SMPIT Al Fityan School Gowa, including the formation of a committee, analysis of student needs, making announcements of new students, posting/sending announcements of new students; 2) the student recruitment process at SMPIT Al Fityan School Gowa, carried out in accordance with the school's PPDB procedures including registration of new students, selection of new students, meeting of accepted students, announcement of accepted students, and re-registration of new students; 3) the output of student recruitment at SMPIT Al Fityan School Gowa includes the average knowledge and skill score of students above 80; attitude assessment includes character, creative, critical reasoning, independent, nationalist, mutual cooperation, discipline, honest, caring for the environment, confident, likes to read; SMPIT quality standards as seen through the quality report card.
\end{abstract}

Keywords: Recruitment System, Student Recruitment, Quality of Educational Institutions

Abstrak: Penerapan Sistem Rekrutmen Peserta Didik dalam
Meningkatkan Mutu Lembaga Pendidikan di SMPIT Al Fityan School Gowa
Penelitian ini bertujuan untuk: 1) mendeskripsikan input rekrutmen peserta
didik di SMPIT Al Fityan School Gowa; 2) mendeskripsikan process rekrutmen
peserta didik di SMPIT Al Fityan School Gowa; 3) mendeskripsikan output
rekrutmen peserta didik di SMPIT Al Fityan School Gowa. Penelitian ini 
menggunakan metode penelitian deskriptif kualitatif. Adapun sumber data penelitian yaitu sekretaris yayasan, kepala sekolah, Ka. Ur. Kesiswaan, Ka. Ur. Kurikulum, tata usaha, ketua panitia PPDB, sekretaris PPDB, dan orang tua siswa. Metode pengumpulan data yang digunakan adalah metode wawancara, observasi dan dokumentasi, dengan teknik pengolahan dan analisis data dilakukan melalui tiga tahapan yaitu data reduction (reduksi data), data display (penyajian data) dan Conclusion Drawing atau Verification (penarikan kesimpulan atau verifikasi). Hasil penelitian ini menunjukkan bahwa: 1) input rekrutmen peserta didik di SMPIT Al Fityan School Gowa, meliputi pembentukan panitia, analisis kebutuhan peserta didik, pembuatan pengumuman peserta didik baru, pemasangan/pengiriman pengumuman peserta didik baru; 2) process rekrutmen peserta didik di SMPIT Al Fityan School Gowa, terlaksana sesuai dengan prosedur PPDB sekolah meliputi pendaftaran peserta didik baru, seleksi peserta didik baru, rapat penentuan peserta didik yang diterima, pengumuman peserta didik yang diterima, dan pendaftaran ulang peserta didik baru; 3) output rekrutmen peserta didik di SMPIT Al Fityan School Gowa meliputi nilai pengetahuan dan keterampilan rata-rata siswa di atas angka 80; penilaian sikap meliputi karakter, kreatif, bernalar kritis, mandiri, nasionalis, gotong royong, disiplin, jujur, peduli lingkungan, percaya diri, gemar membaca; standar mutu SMPIT yang dilihat melalui rapor mutu.

Kata Kunci: Sistem Rekrutmen, Rekrutmen Peserta Didik, Mutu Lembaga Pendidikan

\section{PENDAHULUAN}

Mutu pendidikan di sekolah merupakan pilar penting dalam mewujudkan pendidikan yang bermutu dan berkualitas. Salah satu tugas lembaga pada satuan pendidikan yang merupakan kegiatan tahunan adalah melaksanakan dan menetapkan input sebelum melaksanakan process pendidikan dan pembelajaran. Salah satu input yang terpenting adalah penetapan raw input atau bahan baku, yakni peserta didik. Hal tersebut akan dapat diperoleh dengan baik apabila proses rekrutmen peserta didik baru dapat dilaksanakan secara baik, adil, objektif (Lestari, 2017).

Mutu sebuah lembaga pendidikan dapat ditentukan oleh komponenkomponen pendukung, seperti kurikulum, pembiayaan, dan sarana prasarana sebagai penunjang kegiatan lembaga pendidikan. Komponen lain yaitu komponen sumber daya manusia seperti kepala sekolah, guru, dan peserta didik. Komponenkomponen tersebut merupakan satu-kesatuan yang tak terpisahkan dalam upaya pencapaian tujuan lembaga pendidikan, artinya satu komponen tidak lebih penting dari komponen lainnya. Akan tetapi, satu komponen memberikan dukungan terhadap komponen yang lainnya sehingga memberikan kontribusi yang maksimal 
terhadap pencapaian tujuan lembaga pendidikan. Upaya peningkatan mutu pendidikan secara nasional di setiap satuan pendidikan, diarahkan pada upaya terselenggaranya layanan pendidikan kepada masyarakat yang salah satunya adalah penerimaan peserta didik baru. Penerimaan peserta didik baru adalah kegiatan yang pertama kali dilakukan dalam sebuah lembaga pendidikan, yang tentunya dilakukan melalui proses penyeleksian yang telah ditentukan oleh pihak lembaga pendidikan kepada calon peserta didik baru. Dengan persyaratan tertentu, rekrutmen peserta didik baru harus dilakukan secara terorganisir dan terencana secara sistematis sedemikian rupa, sehingga perekrutan terhadap calon peserta didik baru memenuhi kriteria yang disiapkan oleh sebuah lembaga pendidikan (Ubaidillah, 2017).

Peserta didik dalam pendidikan memiliki posisi yang sangat penting, tanpa peserta didik pendidikan tidak mungkin bisa dijalankan. Menurut Nurhadi (2012), peserta didik di sekolah berkedudukan sentral sebagai pusat segala kegiatan proses belajar mengajar. Peserta didiklah yang akan menjadi masukan dan peserta didiklah yang diharapkan akan mengalami perkembangan dan pertumbuhan di sekolah seperti yang diharapkan dalam tujuan instruksional pendidikan. Oleh sebab itu semua unsur yang ada dalam organisasi pendidikan pada akhirnya harus bermuara pada peserta didik.

Peserta didik merupakan salah satu komponen sekolah yang keberadaannya sangat dibutuhkan, terlebih bahwa pelaksanaan kegiatan pendidikan di sekolah, peserta didik merupakan objek dalam proses transformasi ilmu pengetahuan dan keterampilan-keterampilan. Oleh karena itu keberadaan peserta didik tidak hanya sekedar memenuhi kebutuhan saja, akan tetapi juga merupakan ujung tombak dalam menciptakan lembaga pendidikan yang bermutu. Sehingga peserta didik dapat tumbuh dan berkembang sesuai dengan potensi yang dimilikinya, mulai potensi fisik, kecerdasan intelektual, sosial, emosional.

Dalam Undang-Undang Dasar 1945 tentang Sistem Pendidikan Nasional pada Bab III tentang Hak Warga Negara untuk Memperoleh Pendidikan Pasal 7 berbunyi:

"Penerimaan seseorang sebagai peserta didik dalam suatu satuan pendidikan diselenggarakan dengan tidak membedakan jenis kelamin, agama, suku, ras, kedudukan sosial dan tingkat kemampuan ekonomi, dan dengan tetap mengindahkan kekhususan satuan pendidikan yang bersangkutan" (Republik Indonesia, 2003; h. 3)

Selanjutnya pada bab VII tentang Peserta Didik Pasal V berbunyi:

"Setiap peserta didik pada setiap satuan pendidikan berhak: a) mendapatkan beasiswa bagi yang berprestasi yang orang tuanya tidak mampu membiayai pendidikannya; b) mendapatkan biaya pendidikan bagi mereka yang orang 
tuanya tidak mampu membiayai pendidikannya" (Republik Indonesia, 2003; h. 5)

Hasibuan $(2010,40)$ mengemukakan bahwa rekrutmen peserta didik adalah suatu proses untuk mendorong para calon peserta didik yang potensial untuk masuk atau mendaftar pada program, kursus, kelas, atau madrasah tertentu. Panitia PPDB yang ditugaskan dalam merekrut peserta didik adalah orang yang bertanggung jawab dan amanah. Hal ini juga sesuai diisyaratkan oleh Rasulullah saw. sebagai berikut:

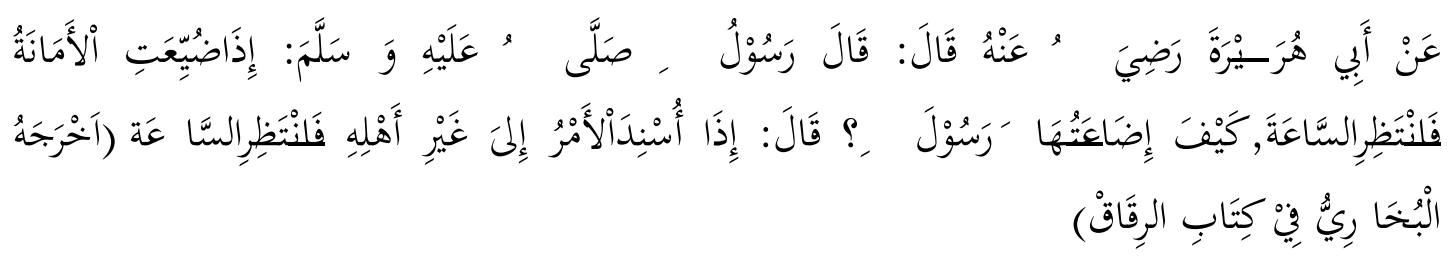

"Dari Abu Hurairah r.a. berkata, Rasulullah SAW bersabda: Apabila amanah disia-siakan maka tunggulah saat kehancurannya. Salah seorang sahabat bertanya:"Bagaimanakah menyia-nyiakannya, hai Rasulullah?" Rasulullah SAW menjawab: "Apabila perkara itu diserahkan kepada orang yang bukan ahlinya, maka tunggulah saat kehancurannya”. (Al-Bukhâri, 1440 H; h. 20).

Hadis tersebut dapat dikaitkan pada rekrutmen peserta didik bahwa yang menjadi panitia PPDB adalah orang yang amanah dalam menjalankan tugasnya sehingga siswa yang diterima pada suatu sekolah sesuai kriteria/syarat pada setiap tahapan-tahapan dalam pelaksanaan rekrutmen peserta didik, sehingga peserta didik yang diterima sesuai dengan ketentuan pemerintah dan lembaga pendidikan, sehingga berpeluang besar untuk menunjang tercapainya tujuan sekolah. Karena langkah pertama yang mencerminkan berhasil tidaknya suatu lembaga pendidikan dalam mencapai tujuannya, jika peserta didik yang diterima mempunyai kompetensi sesuai syarat, maka usaha untuk mewujudkan tujuan lembaga pendidikan relatif mudah, demikian pula sebaliknya.

Namun pada kenyataannya temuan OMBUDSMAN RI berdasarkan pemantauan di 32 provinsi seluruh indonesia, pelaksanaan rekrutmen peserta didik baru tidak terlepas dari berbagai permasalahan, seperti kasus pemungutan uang, penyimpangan prosedur kepanitiaan yang tidak kompeten. Selain itu, Wakil Bapak Wali Kota Malang, Sutiaji mengaku sudah tiga kali mengaku mendapat kiriman pesan pendek yang berisi tentang permintaan tolong untuk memasukkan anak sang pengirim pesan ke sekolah favorit (Ubaidillah, 2017). Terkait banyaknya permasalahan dalam proses PPDB di berbagai sekolah/lembaga pendidikan, maka diperlukan suatu pembenahan pada sistem rekrutmen peserta didik yaitu membangun kepercayaan dengan melakukan transparansi dalam sistem PPDB. 
Mohammad Imam Ardhi berpendapat bahwa sistem rekrutmen peserta didik baru menempati posisi yang sangat urgent dalam menentukan kualitas peserta didik sesuai dengan standar lembaga pendidikan, dimana apabila dalam proses rekrutmen terjadi banyak penyimpangan akan berdampak kepada tidak terpenuhinya kualitas peserta didik sesuai dengan standar yang telah ditetapkan. Rekrutmen peserta didik baru merupakan gerbang awal yang harus dilalui peserta didik dan lembaga pendidikan di dalam penyaringan obyek-obyek pendidikan. Peristiwa ini penting bagi lembaga pendidikan, karena merupakan titik awal yang menentukan kelancaran tugas suatu sekolah, kesalahan dalam rekrutmen peserta didik baru dapat menentukan sukses tidaknya usaha pendidikan di sekolah yang bersangkutan (Ardhi, 2015). Hal ini sesuai dengan yang diungkapkan oleh Lia \& Arikuntro (2008, h. 58) bahwa kesalahan dalam rekrutmen peserta didik baru dapat menentukan sukses tidaknya usaha pendidikan di sekolah.

Fajariana menyatakan bahwa; 1) Perceived quality of inputs that significantly influence students' learning achievement, 2) The competence of teachers is significant effect on student achievement, 3) School infrastructure significant effect on learning achievement, and 4) Motivation to study no significant effect on learning achievement. Dari hasil penelitian tersebut menunjukkan bahwa pelaksanaan PPDB harus selalu diupayakan agar dapat memperoleh calon peserta didik yang mempunyai prestasi belajar yang baik. Dengan harapan prestasi belajar tersebut dapat mempertahankan sampai pada jenjang yang lebih tinggi, maka dengan mudah tujuan pendidikan nasional dicapai sebagaimana tergambar dari prestasi belajar peserta didik yang baik. Lebih lanjut, Sudtrajad \& Utami (2015) mengemukakan bahwa tidak semua peserta didik yang masuk adalah peserta didik yang benar-benar berprestasi, tidak sedikit dari mereka menggunakan berbagai cara dengan memaksimalkan modal yang memiliki untuk mencapai tujuannya.

Beberapa studi terdahulu tersebut menunjukkan pentingnya rekrutmen peserta didik baru yang menuntut lembaga pendidikan mempunyai sebuah sistem rekrutmen peserta didik yang baik dan memilih orang-orang yang bertanggung jawab dalam kegiatan penerimaan peserta didik baru, sehingga dengan mudah lembaga pendidikan tersebut mencapai tujuan pendidikan nasional. Upaya mencapai tujuan pendidikan nasional telah dilakukan oleh semua pihak. Meningkatkan mutu pendidikan ke arah yang lebih baik melalui sumber daya baik fisik, non fisik maupun manusia.

Latar belakang yang menjadi permasalahan dilakukannya penelitian ini adalah biaya pendaftaran di SMPIT Al Fityan School Gowa sebesar Rp. 500.000-, yang mengalahkan biaya pendaftaran sekolah umum dan menyamai biaya pendaftaran pasca sarjana UIN Alauddin Makassar, sehingga sekolah Al Fityan diberi label dengan sekolah "orang kaya", hal ini dibuktikan dengan profesi orang 
tua peserta didik yaitu: guru besar, rektor, dekan, pengacara, pengusaha, dan lainlain. Peserta didik yang mendaftar di sekolah Al Fityan pada intinya mereka yang memiliki biaya yang cukup, sehingga sebagian besar orang tua yang mendaftarkan anaknya di sekolah Al Fityan adalah mereka yang mampu atau memiliki strata ekonomi tinggi.

Alasan utama orang tua mendaftarkan anaknya di SMPIT Al Fityan adalah perubahan karakter pada anak, hafalan Al-quran, dan iman serta akhlak anaknya yang sangat berbeda sebelum dan setelah masuk di Al Fityan. Orang tua yang ingin mendaftarkan anaknya di sekolah Al Fityan namun terkendala pada biaya, harus beralih mendaftarkan anaknya pada sekolah lain. Hal ini merupakan hal yang menarik perhatian peneliti, mengenai sistem rekrutmen peserta didik di Al Fityan dan mengenai mutu pendidikan di Al Fityan itu sendiri. Pertanyaan yang muncul kemudian di benak peneliti apakah Al Fityan terutama SMPIT Al Fityan tidak menerima peserta didik yang kurang mampu? Tidak adakah beasiswa bagi peserta didik yang ingin merasakan mengenyam pendidikan di SMPIT Al Fityan? Mengapa Al Fityan hanya menerima peserta didik yang memiliki orang tua yang berpenghasilan tinggi atau menengah ke atas? Apakah Al Fityan sekolah yang diperuntukkan hanya untuk orang-orang yang menengah ke atas? Dalam undangundang dasar tahun 1945 pasal 31 ayat 1 menyatakan bahwa setiap warga negara wajib mengikuti pendidikan dasar dan pemerintah wajib membiayainya. Yang selanjutnya direalisasikan dengan menerbitkan peraturan pemerintah No. 47 tahun 2008 tentang wajib belajar yang merupakan pelaksanaan dari UU sistem pendidikan nasional No. 20 tahun 2003.

Al Fityan sebagai sekolah tentu tidak boleh hanya menerima peserta didik yang memiliki ekonomi tinggi. Namun juga harus menerima peserta didik dengan ekonomi yang rendah. Adapun tujuan penelitian ini, yaitu untuk mendeskripsikan input rekrutmen peserta didik di SMPIT Al Fityan School Gowa, untuk mendeskripsikan process rekrutmen peserta didik di SMPIT Al Fityan School Gowa, untuk mendeskripsikan output rekrutmen peserta didik di SMPIT Al Fityan School Gowa.

\section{METODE PENELITIAN}

Jenis penelitian ini adalah penelitian deskriptif kualitatif yang betujuan untuk memperoleh informasi dan mengungkapkan situasi dan permasalahan berdasarkan data-data dalam kata-kata. Menurut Muslimin (2016, h. 35), Pendekatan kualitatif yaitu untuk mengetahui atau menggambarkan kenyataan atau kejadian yang diteliti dengan cara mendeskripsikan dalam bentuk kata-kata dan bahasa, pada suatu konteks khusus yang alamiah dan dengan memanfaatkan berbagai metode ilmiah. 
St. Syarifah Syahri Banrimanurung, Baharuddin, Muhammad Rusmin B.

Penelitian ini dilakukan di SMPIT Al Fityan School Gowa, Kabupaten Gowa, Provinsi Sulawesi Selatan. Al Fityan School Gowa menghadirkan lembaga pendidikan yang berkualitas dengan visi menjadi lembaga pendidikan yang terdepan dalam mewujudkan generasi unggul berkarakter islami dan cinta Alquran. Penelitian ini mengunakan dua jenis data yaitu, sumber data primer dan sumber data sekunder. Penelitian ini menggunakan 3 metode pengumpulan data yaitu metode observasi, wawancara dan dokumentasi. Teknik pengolahan dan analisis data yaitu menggunakan data reduction (reduksi data), data display (penyajian data) dan Conclusion Drawing atau Verification (Penarikan Kesimpulan).

\section{HASIL DAN PEMBAHASAN}

Pada bab ini akan diuraikan tentang gambaran data penelitian umum yang akan ditampilkan dalam bentuk rangkuman. Dalam hal ini akan diuraikan hasil penelitian yang dilanjutkan pembahasan dari hasil tersebut. Hasil yang diperoleh untuk memberikan jawaban terhadap masalah penelitian akan diuraikan sebagai berikut.

\section{Input Rekrutmen Peserta Didik di SMPIT Al Fityan School Gowa}

Input rekrutmen peserta didik adalah satu kesatuan proses yaitu pembentukan panitia, analisis kebutuhan peserta didik, pembuatan pengumuman peserta didik baru, dan pemasangan/pengiriman pengumuman peserta didik baru. Hal tersebut dapat dilihat dari hasil penelitian sebagai berikut:

Kepanitiaan PPDB terdiri dari dua bagian yaitu kepanitiaan Unit dan kepanitiaan pusat/Yayasan. Adapun kepanitiaan pusat/Yayasan terdiri dari Badan Pengurus Harian Yayasan dan kepanitiaan unit terdiri dari: 1) kepala sekolah, 2) koordinator yaitu Ka. Ur. kesiswaan, 3) ketua yaitu Ka. Ur. kesiswaan, 4) sekretaris PPDB yaitu wali kelas, 5) bendahara yaitu Ka. Ur. tata usaha. Sedangkan pelaksana rekrutmen yaitu semua guru SMPIT Al Fityan yang sudah lama mengabdi yang sudah diakui kinerjanya. Selanjutnya pengumuman PPDB dimulai pada bulan Januari melalui media elektronik/sosial dan pemasangan spanduk, baliho dan pamflet di beberapa titik di jalan. Jumlah peserta didik yang akan diterima 160, 5 rombel, setiap rombel berjumlah 33 peserta didik. Batas pengumuman PPDB sampai kuota terpenuhi.

\section{Process Rekrutmen Peserta Didik di SMPIT Al Fityan School Gowa}

Process sistem rekrutmen peserta didik adalah pelaksanaan rekrutmen peserta didik meliputi pendaftaran peserta didik baru, seleksi peserta didik baru, rapat penentuan peserta didik yang diterima, pengumuman peserta didik yang 
diterima, dan pendaftaran ulang peserta didik baru. Hal ini dapat dilihat dari hasil penelitian sebagai berikut:

Proses pendaftaran di SMPIT Al Fityan dilakukan melalui website www.fityangowa.sch.id secara online. Bagi orang tua yang belum terampil dalam hal teknologi dan mengalami kendala dalam mendaftarkan anaknya dapat langsung ke sekolah dibantu mendaftar oleh pihak panitia. Adapun biaya pendaftaran sebesar Rp. 500.000,- merupakan biaya yang wajar karena dari biaya pendaftaran tersebut digunakan untuk biaya operasional tes seleksi, pengiklanan, Facebook, Instagram, biaya maintenance website dan itu setiap tahun yang diupgrade dan juga dialokasikan untuk membantu biaya operasional bagi peserta didik yatim. Selanjutnya, seleksi dilaksanakan dengan beberapa tes yaitu tes akademik, tes baca al-Qur'an, psikotes, tes wawancara siswa dan orang tua.

Peserta didik yang dinyatakan lulus, akan dilanjutkan dengan pendaftaran ulang disertai dengan melengkapi berkas-berkas dan mengikuti Masa Pengenalan Lingkungan Sekolah (MPLS). Namun, bagi peserta didik yang tidak lulus tes, jika masuk dalam daftar cadangan akan menunggu selama 1 bulan, namun jika tidak masuk dalam daftar cadangan maka harus mengikuti tes tahun berikutnya. Pengumuman PPDB dilaksanakan di bulan Februari, yang terlibat pada rapat tersebut, yaitu manajemen unit, hasil rapat dari unit selanjutnya dibawa ke Yayasan/Badan Pengurus Harian Yayasan (BPH) selanjutnya dikeluarkan SK kelulusan, bagi peserta didik yang dinyatakan lulus selanjutnya melakukan proses pendaftaran ulang dengan melengkapi berkas pendaftaran ulang yaitu: a) surat berbadan sehat, kartu keluarga; b) tanda tangan surat perjanjian (peraturan umum sekolah); c) tanda tangan kontrak keuangan (70 \% akan dikembalikan uang setelah 7 hari sudah membayar kemudian berhenti, 50\% ketika 2 minggu, lebih dari 1 bulan tidak dikembalikan). Setelah pendaftaran ulang peserta didik mengikuti kegiatan Masa Pengenalan Lingkungan Sekolah (MPLS).

Alasan orang tua mendaftarkan anak mereka di Al Fityan, khususnya di SMPIT karena sekolah tersebut menyeimbangkan pembelajaran umum dan agama, pembelajaran berbasis Al-quran dan pembentukan karakter anak-anak sangat terlihat perubahan karakternya ketika sekolah di Al Fityan. Di samping itu, biaya pendaftaran di Al Fityan masih lebih murah dibandingkan dengan sekolah IT lainnya yang ada di Makassar.

\section{Output Rekrutmen Peserta Didik dalam meningkatkan Mutu Lembaga Pendidikan di SMPIT Al Fityan School}

Output rekrutmen peserta didik meliputi : 1) Dampak proses rekrutmen peserta didik terhadap mutu pendidikan; 2) Jumlah alumni siswa SMPIT lanjut ke SMAIT; 3) standar mutu SMPIT; 4) nilai rapor mutu SMPIT, 5) Nilai pengetahuan 
rata-rata siswa kelas 3 SMPIT; 6) Nilai keterampilan rata-rata siswa kelas 3 SMPIT; 7) penilaian sikap; 8) standar nilai sikap untuk lulus; dan 9) Akreditasi SMPIT.

Rekrutmen peserta didik sangat berdampak pada kualitas peserta didik tentunya berdampak juga pada lembaga pendidikan, karena jika input peserta didik bagus, process peserta didik bagus, maka output peserta pasti bagus. Rekrutmen peserta didik untuk mengetahui tingkat kemampuan awal peserta didik pada pengetahuan akdemik, pada baca tulis al-Qur'an dan pada hafalan alQur'an sehingga memudahkan para guru dalam proses pembelajaran. Selanjutnya tidak semua alumni SMPIT yang lanjut ke SMAIT, tetapi sekitar 90\% alumni SMPIT diterima di SMAIT dan tetap dilakukan tes seleksi dan jika nilai tesnya tidak cukup, maka tidak diterima. Adapun kebijakan mutu di SMPIT Al Fityan kemudian diuraikan menjadi sasaran mutu tiap bagian di sekolah seperti sasaran mutu kepala sekolah, sasaran mutu kurikulum, sasaran mutu kesiswaan, dan sasaran mutu tata usaha.

Uraian sasaran mutu fungsinya sebagai standar untuk mencapai atau mewujudkan target dalam meningkatkan kualitas lembaga guna mencapai kebijakan mutu SMPIT Al Fityan School Gowa yang dimonitoring dan dievaluasi setiap semester atas ketercapaian sasaran mutu tiap bagian. Nilai rapor mutu SMPIT Al Fityan pada masing-masing standar pendidikan nasional di atas angka 5 yang menunjukkan bahwa nilai tersebut baik. Adapun nilai pengetahuan dan keterampilan rata-rata peserta didik SMPIT Al Fityan kelas 3 di atas angka 80. Sedangkan nilai sikap sosial yang dinilai pada siswa SMPIT Al Fityan yaitu karakter kreatif, bernalar kritis, mandiri, nasionalis, gotong royong, disiplin, jujur, peduli lingkungan, percaya diri, gemar membaca. nilai akreditasi SMPIT Al Fityan mencapai nilai akhir yang pada tabel klasifikasi yang jika di konversi ke peringkat berada pada peringkat " $A$ " dengan predikat "Unggul" yang masa berlaku sertifikat Akreditasi tersebut sampai 23 November 2022.

Hasil penelitian ini menunjukkan bahwa penerapan sistem rekrutmen peserta didik di SMPIT Al Fityan School Gowa telah berjalan dengan baik sesuai dengan kebijakan yang telah ditetapkan oleh sekolah dan sesuai dengan standar yang telah ditetapkan oleh pemerintah pusat. Hal ini dapat dilihat dengan pelibatan seluruh stakeholder sekolah meliputi pembentukan panitia, analisis kebutuhan peserta didik, pembuatan pengumuman peserta didik baru, pemasangan/pengiriman pengumuman peserta didik baru, pendaftaran peserta didik baru, seleksi peserta didik baru, rapat penentuan peserta didik yang diterima, pengumuman peserta didik yang diterima, dan pendaftaran ulang peserta didik baru. walaupun dalam pelaksanaan rekrutmen pada program beasiswa yang disediakan oleh sekolah terbatas pada program beasiswa yatim 
dengan jumlah kuota 10 orang sehingga siswa yang ingin mengenyam pendidikan di AL Fityan dan terkendala pada biaya harus beralih mendaftar ke sekolah lain.

Peningkatan mutu pendidikan menunjukkan bahwa peningkatan mutu pendidikan di SMPIT Al Fityan School Gowa diterapkan sesuai sistem manajemen mutu bertaraf internasional ISO 9001 versi 2015 dan tersertifikasi. Hal ini dapat dilihat dari nilai pengetahuan dan keterampilan rata-rata siswa di atas angka 80, penilaian sikap yang dinilai yaitu karakter kreatif, bernalar kritis, mandiri, nasionalis, gotong royong, disiplin, jujur, peduli lingkungan, percaya diri, gemar membaca. Standar mutu SMPIT meliputi nilai rapor mutu pada setiap standar nasional pendidikan di atas angka 5, nilai akreditasi SMPIT yaitu A, kebijakan mutu diuraikan menjadi sasaran mutu tiap bagian di sekolah seperti saran mutu kepala sekolah, sasaran mutu kurikulum, sasaran mutu kesiswaan, dan sasaran mutu tata usaha dan sasaran mutu PPDB. Hasil penelitian ini berdasarkan Peraturan Pemerintah Nomor 19 Tahun 2005 tentang Standar Nasional Pendidikan yaitu standar kelulusan meliputi penilaian sikap, penilaian pengetahuan dan penilaian keterampilan.

\section{PENUTUP}

Sistem rekrutmen peserta didik di SMPIT Al Fityan School Gowa dapat dilihat melalui: 1) Input rekrutmen peserta didik di SMPIT Al Fityan School Gowa, telah berjalan dengan baik sesuai dengan kebijakan yang telah ditetapkan oleh sekolah dan sesuai dengan standar yang telah ditetapkan oleh pemerintah pusat; 2) Process rekrutmen peserta didik di SMPIT Al Fityan School Gowa, meliputi pendaftaran peserta didik baru, seleksi peserta didik baru, rapat penentuan peserta didik yang diterima, pengumuman peserta didik yang diterima, dan pendaftaran ulang peserta didik baru. walaupun dalam pelaksanaan rekrutmen pada program beasiswa yang disediakan oleh sekolah terbatas pada program beasiswa yatim dengan jumlah kuota 10 orang sehingga peserta didik yang ingin mengenyam pendidikan di AL Fityan dan terkendala pada biaya harus beralih mendaftar ke sekolah lain; 3) Output rekrutmen peserta didik di SMPIT Al Fityan School Gowa dilihat dari nilai pengetahuan dan keterampilan rata-rata siswa di atas angka 80, penilaian sikap yang dinilai yaitu karakter kreatif, bernalar kritis, mandiri, nasionalis, gotong royong, disiplin, jujur, peduli lingkungan, percaya diri, gemar membaca, standar mutu SMPIT meliputi nilai rapor mutu di atas angka 5, nilai akreditasi SMPIT yaitu A, kebijakan mutu diuraikan menjadi sasaran mutu tiap bagian di sekolah seperti saran mutu kepala sekolah, sasaran mutu kurikulum, sasaran mutu kesiswaan, dan sasaran mutu tata usaha dan sasaran mutu PPDB.

Direktur/yayasan, kepala sekolah beserta tenaga pendidik di SMPIT Al Fityan School Gowa sebaiknya menambah relasi atau mitra dalam hal penambahan kuota 
St. Syarifah Syahri Banrimanurung, Baharuddin, Muhammad Rusmin B.

beasiswa yatim, dan menambah program beasiswa yaitu beasiswa berprestasi, dan tahfidz. Sehingga siswa yang ingin mengenyam pendidikan dan terkendala pada biaya bisa mendapatkan kesempatan sekolah di Al Fiyan Scool Gowa.

\section{DAFTAR PUSTAKA}

Al-Bukhâri, I. bin M. (1440 H). Al-Jâmi'Ash-Shahî. Qâhirah: Al-Mathba'ah asSalafiyah.

Ardhi, I. M. (2015). Evaluasi Manajemen Penerimaan Peserta Didik Baru. Yogyakarta: Sistem Real Time Online Dinas Pendidikan.

Hasibuan, M. (2010). Manajemen Sumber Daya Manusia. Jakarta: Bumi Aksara.

Lestari, E. (2017). Sistem Rekrumen peserta didik. Tesis: Fakultas Tarbiyah Dan Ilmu Keguruan IAIN Puwokerto.

Lia, Y., \& Arikuntro, S. (2008). Manajemen Pendidikan. Yogyakarta: Aditya Media.

Nurhadi, M. A. (2012). Administrasi Pendidikan Disekolah. Yogyakarta: Andi Offset.

Republik Indonesia. (2003). Undang-Undang Nomor 20 Tahun 2003 Tentang Sistem Pendidikan Nasional. Jakarta: Yayasan Peduli Anak Negeri.

Sudtrajad, A., \& Utami, P. (2015). Praktek Sosial Peserta Didik dalam Memasuki SMA Negeri Kudungwaru di kabupaten Tulungagung. Jurnal, 31.

Ubaidillah, A. (2017). Strategi Rekrutmen Peserta Didik dalam Meningkatkan Mutu Lembaga Pendidikan. Malang: Universitas Islam Negeri Maulana Malik Ibrahim. 